\title{
Ondine's curse: the origin of the myth
}

\author{
La maldición de Ondina: el origen del mito \\ Eduardo ORREGO-GONZÁLEZ, Germán José MEDINA-RINCÓN, \\ Sofia MARTÍNEZ-GIL, Juan Sebastián BOTERO-MENESES
}

\begin{abstract}
Central alveolar hypoventilation syndrome has been known for decades as Ondine's curse. It was named as such after a German myth. Although most of the stories resemble one another, word of mouth has led to misinterpretation of this tale among the medical community. The present paper reviews the original narrative, its characters, and how it is linked to the most relevant aspects of the disease.
\end{abstract}

Keywords: Sleep apnea, central; pulmonary medicine; literature; mythology.

\section{RESUMEN}

El síndrome de hipoventilación alveolar central (por sus siglas en inglés) se conoce desde hace décadas como la maldición de Ondine. Fue nombrado como tal por un antiguo mito alemán. Aunque la mayoría de las historias se parecen, la tradición oral ha llevado a una mala interpretación de esta historia entre la comunidad médica. El presente artículo revisa la narrativa original, sus personajes y su relación con los aspectos más relevantes de la enfermedad.

Palabras-clave: apneia do sono tipo central; pneumologia; literatura; mitologia.

"Ondine's curse" is a rather interesting example of the use of a tale in modern medical vernacular. In this case, the story has been used throughout history to explain the many cases of people who have died while asleep. The common belief is that a water spirit "Undine" cursed her lover, making it impossible for him to breathe while sleeping. We review the origins of this tale and how it links to the real-world disease.

Friederich Heinrich Karl de la Motte, Baron Fouqué (1777-1843), was a journalist, playwright, poet, and publisher of romantic literature. He published the story about Undine for the first time, in $1811^{1}$. Paracelsus wrote about Undine before the German writer, who recognized that his work was partially based on Paracelsus' writings ${ }^{2}$. In these writings, he coined the terms for the four elements and its characteristics. "Undine" (Latin Unda for wave) was the term used to describe the water spirit ${ }^{3}$. After multiple adaptations, plays, and versions in the French language, the term Undine was replaced by "Ondine", which is the French word for water spirit ${ }^{3}$ (Figure 1).

In the original version of the tale, it was said that there was once a water prince living underwater in his kingdom, who had a daughter called "Undine." These water people lacked a soul. The water prince wanted his daughter, Undine, to possess a soul ${ }^{4}$. So he sent Undine to the surface, because "the only way to obtain a soul was by achieving an intimate union in love with a mortal man." The princess was adopted by a fisherman and his wife, who lived by a deep and dark lake (Figure 2). The couple had lost their young daughter years before, when she had disappeared into the lake. Upon coming of age, the princess Undine ran into a handsome knight, the Count Huldbrand of Ringstetten, who had been led into the woods and got lost. This was the work of Kuhleborn, Undine's uncle, who wanted to fulfill the desires of the prince. Shortly after that, they fell in love and were betrothed, allowing Undine to obtain a soul ${ }^{4}$.

This happiness was, however, short lived, as Undine soon discovered that her husband already had a lover, Bertalda ${ }^{4}$. She was none other than the lost daughter of Undine's adoptive parents. Huldbrand had cheated on Undine with Bertalda, which enraged Kuhleborn. Furious, he appeared from a fountain in the count's castle, to threaten Bertalda and the knight for his unfaithfulness ${ }^{4}$. However, the princess Undine blocked the fountain because she still loved the knight. Later, Kuhleborn

Universidad del Rosario, School of Medicine and Health Sciences, Neuroscience Research Group NEUROS, Bogotá, Colombia.

Correspondence: Juan Sebastian Botero Meneses; Neuroscience Research Group NEUROS, School of Medicine and Health Sciences; Carrera 24 \# 63c-74, Bogotá, Colombia; E-mail: juans.botero@urosario.edu.co

Eduardo Orrego-González (iD) https://orcid.org/0000-0002-8406-4153; Germán José Medina-Rincon iD https://orcid.org/0000-0003-2874-3669; Sofía Martínez-Gil (iD) https://orcid.org/0000-0002-6911-8264;Juan Sebastián Botero-Meneses iD https://orcid.org/0000-0003-1849-8751

Conflict of interest: There is no conflict of interest to declare.

Received 22 April 2019; Received in final form 04 June 2019; Accepted 16 June 2019. 


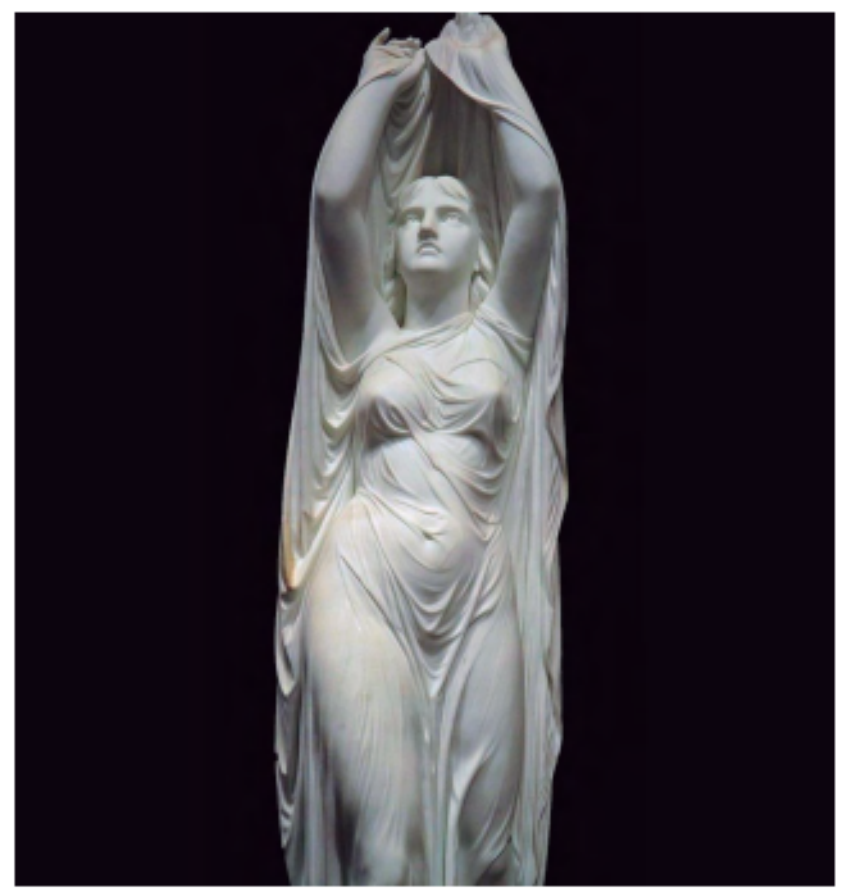

Figure 1. Undine Rising from the Waters - Chauncey Bradley Ives.

warned Undine that the punishment for Huldbrand's betrayal would be death. The omen was fulfilled only a few years later when the knight and Bertalda decided to get married. Undine visited the knight in his room one last time.

"And, trembling with love and with the nearness of death, the knight bent towards her, and she kissed him with a holy kiss. But she did not again draw back, she pressed him to her ever closer and closer...Tears rushed into Huldbrand's eyes, and his breast surged and heaved, till, at the last, breath failed him, and he fell back softly from Undine's arms upon the pillows of his couch-dead"4.

The tale of Undine became a popular subject for plays and adaptations. One famous adaptation of the romance was Jean Giraudoux's play of the same name ${ }^{5}$. In this play, after the knight broke his commitment to Ondine, she and the king of Ondins met.

"LE ROI DES ONDINS (King of Ondins): La fin approche, Ondine... (The end is near, Ondine)

ONDINE: Ne le tue pas. (Do not kill him)

LE ROI DES ONDINS: Notre pacte le veut. Il t'a trompée. (Our pact wants it. He cheated on you)"s.

Later in Giraudoux's play, Ondine visited the knight, and he moaned to her: "...Since you left, everything my body should do by itself I have to command it to do... One moment of inattention and I shall forget to hear, to breathe... It would be said that he died because breathing bored him...". In Giraudoux's version, it was implied that the knight was cursed, and Ondine was blamed for it; however, it has been stated in all other versions, that this is not true $e^{2,3}$.

Central alveolar hypoventilation syndrome, also known as “Ondine's curse", is typically described as a congenital condition

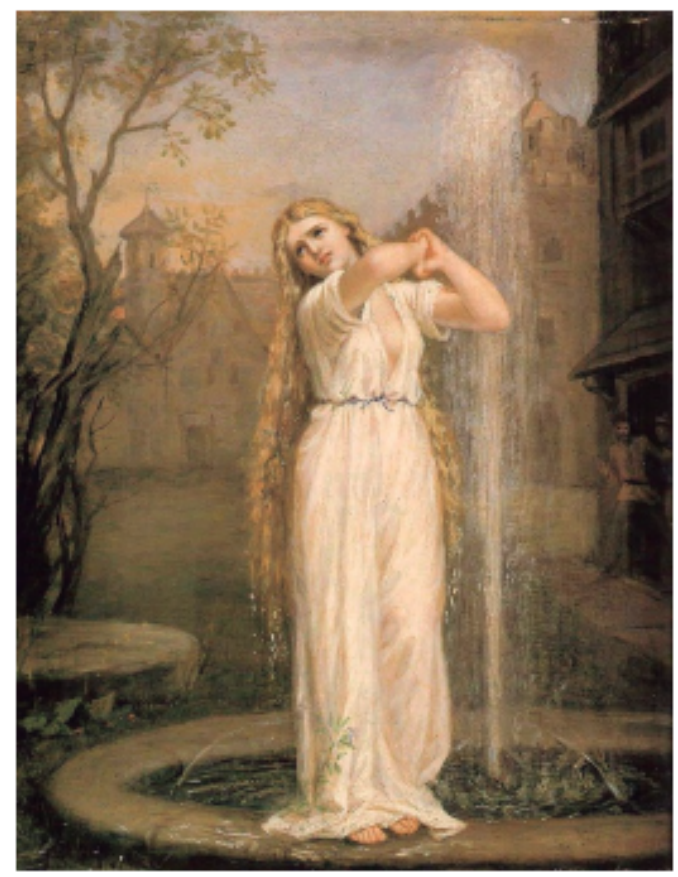

Figure 2. "Undine" oil canvas by John William Waterhouse, 1872.

due to a mutation of the $P H O X 2 B$ gene ${ }^{6,7,8}$. It belongs to the central hypoventilation syndrome category, which includes other congenital causes of Ondine's curse, including the rapid-onset obesity with hypothalamic dysfunction, familial dysautonomia, and Chiari type II malformation; and acquired causes such as brain tumors, central nervous system infections, and cerebrovascular diseases ${ }^{6,7,8}$. The origin of this term can be retraced to Severinghaus and Mitchell who, in 1962, studied three patients who underwent spinothalamic tract cordotomy and subsequently developed apnea episodes during sleep ${ }^{1}$. The syndrome was named after the German legend about a water spirit (de la Motte Fouqués version) $)^{9,10}$.

This syndrome features a failure of the central respiratory drive to breathe during sleep, leading to insufficient ventilation and respiratory failure ${ }^{11}$. Typically, this occurs during non-rapid eye movement sleep, when the ventilatory drive is controlled almost entirely by metabolic input; resulting in hypercapnia or hypoxemia ${ }^{11}$. Patients with congenital hypoventilation not only lack appropriate ventilatory responses to hypercapnia and hypoxia, but they also lack the sensations and physical symptoms of respiratory compromise such as dyspnea and discomfort ${ }^{6,12,13}$.

As we have seen, the story behind Ondine's syndrome is often misquoted and misinterpreted. It is hard to believe that some people in the world have to live under the constant fear of dying in their sleep, for it sounds rather far fetched. This event, apparently impossible to explain, is a sterling example of how literature can bridge science. We would like to clarify that Ondine never did curse anyone, and this is most likely not the cause of congenital central alveolar hypoventilation syndrome. 
1. Friedrich Heinrich Karl de la Motte, Baron Fouqué. Encyclopedia Britannica. [cited 2019 Mar 20]. Available from: https://www. britannica.com/biography/Friedrich-Heinrich-Karl-de-la-MotteBaron-Fouque

2. Nannapaneni R, Behari S, Todd NV, Mendelow AD. Retracing "Ondine's curse". Neurosurgery. 2005 Aug;57(2):35463. https://doi.org/10.1227/01.NEU.0000166684.69422.49

3. Rolak LA. Who was Ondine and what was his curse? J Child Neurol. 1996 Nov;11(6):461. https://doi.org/10.1177/088307389601100609

4. Motte-Fouque FH. Undine a tale by Friederich Baron de la Motte-Fouque. London: Lawrence and Bullan; 1896.

5. GiradouxJ. Ondine: Pièce en trois actes. Paris: Bernard Grasset; 1939.

6. Cielo C, Marcus CL. Central hypoventilation syndromes. Sleep Med Clin. 2014 Mar;9(1):105-18. https://doi.org/10.1016/j.jsmc.2013.10.005

7. Pedroso JL, Baiense RF, Scalzaretto AP, Braga Neto P, Gois AFT, Ferraz ME. Ondine's curse after brainstem infarction. Neurol India. 2009 Apr;57(2):206-7. https://doi.org/10.4103/0028-3886.51298

8. Weese-Mayer DE, Berry-Kravis EM, Zhou L, Maher BS, Silvestri $J M$, Curran ME, et al. Idiopathic congenital central hypoventilation syndrome: analysis of genes pertinent to early autonomic nervous system embryologic development and identification of mutations in PHOX2b. Am J Med Genet A. 2003 Dec;123A(3):267-78. https://doi.org/10.1002/ajmg.a.20527

9. Ondine's curse. JAMA. 1965 Sep;193(12):1048-9.

10. Kuhn M, Lütolf M, Reinhart WH. The eye catcher. Ondine's curse. Respiration. 1999;66(3):265. https://doi.org/10.1159/000029388

11. Maloney MA, Kun SS, Keens TG, Perez IA. Congenital central hypoventilation syndrome: diagnosis and management. Expert Rev Respir Med. 2018 Apr;12(4):283-92. https://doi.org/10.1080/17476348.2018.1445970

12. Fine-Goulden MR, Manna S, Durward A. Cor pulmonale due to congenital central hypoventilation syndrome presenting in adolescence. Pediatr Crit Care Med. 2009 Jul;10(4):e41-2. https://doi.org/10.1097/PCC.0b013e318198b219

13. Kasi AS, Perez IA, Kun SS, Keens TG. Congenital central hypoventilation syndrome: diagnostic and management challenges. Pediatric Health Med Ther. 2016 Aug;7:99-107. https://doi.org/10.2147/PHMT.S95054 